\title{
Development of Squash from Wild Prickly Pear (Opuntia dillenii Haw.) Fruit and Its Quality Evaluation During Storage
}

\author{
N.S. Thakur, Monika Chauhan* and Abhimanyu Thakur
}

Department of Food Science and Technology, Dr YS Parmar University of Horticulture and Forestry, Nauni, Solan - 173230, Himachal Pradesh, India

*Corresponding author

\section{A B S T R A C T}

\section{Keywords}

Opuntia dillenii Haw., Wild prickly pear, Antioxidants, Betalains, Squash

Article Info

Accepted: 15 June 2018 Available Online: 10 July 2018
Wild prickly pear (Opuntia dillenii Haw.), belonging to family Cactaceae grows mainly in arid and semi-arid climate. Its fruits are edible and sweet, which are rich source of antioxidants like phenols and betalains (betacyanins and betaxanthins). Therefore, an attempt was made to develop squash from its fruit and determine quality changes during storage. Different combinations of enzyme assisted extracted juice and sugar syrup were tried and analysed on the basis of sensory quality attributes to standardize proper combination for squash. The squash prepared by following the best selected recipe (35\% juice, $40{ }^{\circ}$ Brix TSS and $1.20 \%$ acidity) was packed in glass and PET bottles and stored for six months under ambient and refrigerated conditions. Squash could be safely stored for a period of six months under both storage conditions without much changes in quality characteristics. However, changes were slower in refrigerated storage conditions as compared to that under ambient conditions. Both the packaging materials viz. PET and glass bottles were found suitable, with comparatively less changes occurring in glass bottles stored under refrigerated conditions.

\section{Introduction}

Wild prickly pear (Opuntia dillenii Haw.) - a xerophytic plant belongs to family cactaceae which grows mainly in arid and semi-arid climate (Parmar and Kaushal, 1982 and Thakur et al., 2012). Wild prickly pear is a non-climacteric, fleshy mucilaginous fruit which is almost berry like, pyriform, depressed at the apex and containing mucilaginous pulp. The overall flowering season starts from the second week of May to the mid of August and the fruiting season is from November to February in certain areas of the country. The fruits of wild prickly pear (Opuntia dillenii Haw.) are edible and sweet, containing sufficient quantity of sugars, with a pleasant blend of acidity (Parmar and Kaushal, 1982). This fruit consists of various antioxidant compounds like ascorbic acid, phenolics, betalains, flavonoids (Kampferrol, Quercetin, Narcissin and Toxifolin), lactones, terpenoids, alkaloids along with unsaturated alchohols and unsaturated aldehydes (Lee et 
al., 2003; Tesoriere et al., 2005 and Saenz et al., 2013). Wild prickly pear has a relatively high level of amino acids like serine, $\gamma$-amino butyric acid, glutamine, proline, arginine, histidine, methionine and minerals like potassium and calcium. Fruits of prickly pear have been used in traditional folk medicine because of its role in treating a number of diseases have diuretic effect, analgesics, antiinflammatory effects, hypoglycemic effects, anti-allergic activity, inhibition of stomach ulcerations, neuroprotective effects and to alleviate alchohol hangover symptoms. Its fruit being rich source of antioxidant compounds helps in treating cancer, Alzheimer's and Parkinson's disease, heart diseases, cataracts and atherosclerosis (Kim et al., 2006). Prickly pear fruits are a good source of fibres which gives the juice a favourable mouth feel and helps to reduce blood sugars and plasma cholesterol levels (Fernandez et al., 1992). So, keeping in view its availability in the waste land and importance with respect to its quality characteristics, this fruit was exploited for the development of certain value added products including squash. Thus, the present studies were undertaken to develop squash from this fruit and its quality evaluation during storage.

\section{Materials and Methods}

\section{Raw material and extraction of juice}

The mature fruits of Opuntia dillenii Haw. procured from Vaknaghat area of Solan district of HP during the year 2016-17 and were used for various physico-chemical analysis and juice extraction. The juice from the fruit was extracted with physical as well as enzymatic mehods (Chauhan et al., 2017).

\section{Development of fruit squash}

The product was prepared by mixing the wild prickly pear juice and sugar syrup as per the different treatment combinations given in Table 1. To get the desirable concentration of acid $(1.20 \%)$ in squash, citric acid was added in all the treatment combinations. Sodium benzoate $(600 \mathrm{ppm})$ was added in all the treatments as a preservative during product preparation. The squash prepared by following the best selected combination on the basis of sensory evaluation was packed in presterilised glass and PET bottles (transparent bottles of $700 \mathrm{ml}$ capacity). All the packed products were properly labelled and stored at ambient $\left(15-25^{\circ} \mathrm{C}\right)$ and refrigerated $\left(4-7{ }^{\circ} \mathrm{C}\right)$ conditions for six months. The physicochemical and sensory characteristics were analyzed at 0, 3 and 6 months of storage.

\section{Physico-chemical analysis and sensory evaluation}

The colour of squash in terms of different units (Red and Yellow) was observed with Tintometer (Lovibond Tintometer Model-E). The apparent viscosity of the squash was determined by using Ostwald viscometer and was expressed in time (flow rate in minutes) taken for samples to pass through the tube. TSS, sugars, titratable acidity and ascorbic acid content of squash were determined according to the standard procedures as described by Ranganna (1997). Total phenols content was determined by Folin-Ciocalteu procedure given by Singleton and Rossi (1965). Betalains were estimated photometrically as per the procedure given by Castellanos-Santiago and Yahia (2008). Antioxidant activity (Free radical scavenging activity) was measured as per the method of Brand-Williams et al., (1995). Nine point hedonic rating test was followed for conducting the sensory evaluation of wild prickly pear squash. The panel of ten judges comprising of faculty members and students of department of Food Science and Technology, Dr Y S Parmar University of Horticulture and Forestry, Nauni, Solan (HP) 
were selected to evaluate the products for sensory parameters such as colour, body, taste, aroma and overall acceptability.

\section{Statistical analysis}

Data on physico-chemical characteristics of squash was analysed by Completely Randomized Design (CRD) before and during storage, whereas, data pertaining to the sensory evaluation were analyzed by using Randomized Block Design (RBD) as described by Mahony (1985). The experiment for recipe standardization was replicated three times and for storage studies five times.

\section{Results and Discussion}

Standardization of recipe for the preparation of wild prickly pear squash

The data pertaining to physico-chemical and sensory characteristics of wild prickly pear prepared by following different recipes are presented in Table 2 and 3.

\section{Physico-chemical characteristics}

Data in Table 2 reveal that visual red and yellow TCU of different recipes ranged between 24.10 to 24.70 and 4.30 to 5.20 , respectively. The maximum red (24.70) and yellow (5.20) TCU were recorded in $\mathrm{T}_{8}$ whereas, the lowest were recorded in $T_{1}$. The betacyanins and betaxanthins content of different recipes of this beverage ranged between 17.01 to 27.25 and 3.69 to 5.93 $\mathrm{mg} / 100 \mathrm{ml}$. The highest $(27.25 \mathrm{mg} / 100 \mathrm{ml})$ value of betacyanins recorded in $\mathrm{T}_{8}$ which was statistically at par with $\mathrm{T}_{4}$ and lowest (17.01 $\mathrm{mg} / 100 \mathrm{ml})$ in $\mathrm{T}_{1}$, whereas, the highest (5.93 $\mathrm{mg} / 100 \mathrm{ml}$ ) value of betaxanthins was recorded in $\mathrm{T}_{8}$ which was at par with $\mathrm{T}_{4}$ and lowest $(3.69 \mathrm{mg} / 100 \mathrm{ml})$ in $\mathrm{T}_{1}$.

The ascorbic acid content of wild prickly pear squash in various treatment combinations ranged between 4.93 to $7.91 \mathrm{mg} / 100 \mathrm{ml}$ and highest $(7.91 \mathrm{mg} / 100 \mathrm{ml})$ was recorded in $\mathrm{T}_{8}$ and the lowest $(4.93 \mathrm{mg} / 100 \mathrm{ml})$ in $\mathrm{T}_{1}$ which was statistically at par with $\mathrm{T}_{5}$. The total phenols content of different recipes of wild prickly pear squash varied from 20.08 to 32.20 $\mathrm{mg} / 100 \mathrm{ml}$. It was recorded highest (32.20 $\mathrm{mg} / 100 \mathrm{ml}$ ) in $\mathrm{T}_{8}$ which was statistically at par with $\mathrm{T}_{4}$ and lowest $(20.08 \mathrm{mg} / 100 \mathrm{ml})$ in $\mathrm{T}_{1}$ which was statistically at par with $T_{5}$. However, the antioxidant activity of all recipes ranged between 17.52 to 28.07 per cent, the highest $(28.07 \%)$ antioxidant activity was recorded in $\mathrm{T}_{8}$ which was at par with $\mathrm{T}_{4}$ and lowest $(17.52 \%)$ in $\mathrm{T}_{1}$ which was statistically at par with $\mathrm{T}_{5}$.

From Table 2 it was concluded that with the increase in juice content of different recipes a significant effect on physico-chemical characteristics of wild prickly pear squash recipes was observed. Data in Table 2 show that recipe $\mathrm{T}_{4}$ and $\mathrm{T}_{8}$ recorded higher values of betacyanins, betaxanthins, total phenols, ascorbic acid and antioxidant activity which were due the higher juice content as compared to other recipes like $T_{1}$ and $T_{5}$. The changes in juice content had also affected the colour units of different recipes of the squash.

\section{Sensory characteristics}

Data on sensory characteristics of different recipes of wild prickly pear squash given in Table 3 indicate that the mean colour score was recorded highest (7.34) in $\mathrm{T}_{8}$ which was statistically at par with $\mathrm{T}_{4}$ and the lowest (7.04) was reported in $T_{1}$. The recipe $T_{3}$ obtained maximum (7.57) body score and minimum in $\mathrm{T}_{7}$ (6.30) which was statistically at par with $\mathrm{T}_{8}$ and $\mathrm{T}_{5}$. The same recipe obtained maximum taste score (8.33) and $\mathrm{T}_{8}$ got the minimum score (5.23) which was statistically at par with $\mathrm{T}_{7}$. The maximum (7.28) score of aroma was obtained in recipe $T_{8}$ which was statistically at par with $\mathrm{T}_{4}$ and minimum (6.90) in $\mathrm{T}_{1}$ which was at par with $T_{5}$. The highest score (7.86) of 
overall acceptability was awarded to recipe $\mathrm{T}_{3}$ followed by $\mathrm{T}_{4}$ and lowest (6.14) in $\mathrm{T}_{8}$ closely followed by $\mathrm{T}_{7}$ and $\mathrm{T}_{1}$.

From the above results it was concluded that the recipe with 35 per cent juice, $40^{\circ} \mathrm{B}$ TSS and 1.20 per cent acidity $\left(\mathrm{T}_{3}\right)$ was found to be the best on the basis of sensory and some physico-chemical characteristics.

This recipe obtained maximum scores for sensory parameters like colour, body, taste, aroma and overall acceptability which might be due to higher juice content, best combination of juice and syrup, best sugaracid blend in the product and finally all these factors might have led the judges to award the highest scores to this recipe.

\section{Storage of wild prickly pear squash}

\section{Physico-chemical characteristics}

\section{Colour}

The red and yellow TCU (Tintometer Colour Units) of squash decreased significantly (Figure 1a and 1b) during storage. However, decrease was significantly lower under refrigerated storage conditions than ambient.

The reason for decrease in colour units of squash during storage might be due to degradation of betalains (betacyanins and betaxanthins).

However, these pigments degraded at slower rate in low temperature hence, less decrease observed in refrigerated conditions. Similar trend of decrease in red and yellow colour units were observed by Thakur and Thakur
(2017) in box myrtle squash and Thakur et al., (2018) in wild pomegranate squash.

\section{Apparent viscosity}

There was a significant increase in apparent viscosity of wild prickly pear squash during storage (Figure 1c) which was more in ambient storage conditions as compared to refrigerated. Increase in apparent viscosity may be due to the increase in strain and shearing rate and decrease in the flow index of the product as a result of increase in TSS and soluble sugars. As the flow index decreases it helps to develop pseudo plasticity and increased the apparent viscosity of the product (Bal et al., 2014). Other reason could be the precipitation of squash caused due to the interaction of sugars with phenols and proteins. Similar results have been reported by Thakur and Thakur (2017) in box myrtle squash and Thakur and Hamid (2017) in mulberry squash.

\section{TSS}

The TSS content of squash increased slightly during storage (Figure 1d) and this increase during storage might be due to partial hydrolysis of complex carbohydrates into monosaccharide and soluble disaccharides (Gould, 1983 and Kannan and Thirumaran, 2002). More increase in TSS was found in squash stored under ambient conditions as compared to refrigerated storage conditions. Our results are in conformity with the findings of Hussain et al., (2005) in mango squash, Relekar et al., (2013) in sapota squash and Sharma et al., (2016) in bitter gourd-kiwi blended squash.

\section{Table.1 Treatment combinations of fruit squash}

\begin{tabular}{|c|c|c|c|c|c|c|c|c|}
\hline Treatment & $\mathbf{T}_{\mathbf{1}}$ & $\mathbf{T}_{\mathbf{2}}$ & $\mathbf{T}_{\mathbf{3}}$ & $\mathbf{T}_{\mathbf{4}}$ & $\mathbf{T}_{\mathbf{5}}$ & $\mathbf{T}_{\mathbf{6}}$ & $\mathbf{T}_{\mathbf{7}}$ & $\mathbf{T}_{\mathbf{8}}$ \\
\hline Juice (\%) & 25 & 30 & 35 & 40 & 25 & 30 & 35 & 40 \\
\hline TSS $\left({ }^{\mathbf{0}} \mathbf{B}\right)$ & 40 & 40 & 40 & 40 & 45 & 45 & 45 & 45 \\
\hline
\end{tabular}




\begin{tabular}{|c|c|c|c|c|c|c|c|}
\hline \multirow{3}{*}{ Treatments } & \multicolumn{7}{|c|}{ Physico-chemical characteristics } \\
\hline & \multicolumn{2}{|c|}{ Colour (TCU) } & \multicolumn{2}{|c|}{$\begin{array}{l}\text { Betalains } \\
(\mathrm{mg} / 100 \mathrm{ml})\end{array}$} & \multirow{2}{*}{$\begin{array}{c}\text { Ascorbic } \\
\text { acid } \\
\text { (mg/100 } \\
\text { ml) }\end{array}$} & \multirow{2}{*}{$\begin{array}{c}\text { Total } \\
\text { phenols } \\
\text { (mg/ 100 } \\
\text { ml) }\end{array}$} & \multirow{2}{*}{$\begin{array}{c}\text { Antioxidan } \\
\text { activity } \\
(\%)\end{array}$} \\
\hline & Red & Yellow & $\begin{array}{l}\text { Beta- } \\
\text { cyanins }\end{array}$ & $\begin{array}{c}\text { Beta- } \\
\text { xanthins }\end{array}$ & & & \\
\hline$T_{1}$ & 24.10 & 4.30 & 17.01 & 3.69 & 4.93 & 20.08 & 17.52 \\
\hline $\mathbf{T}_{2}$ & 24.30 & 4.40 & 20.40 & 4.42 & 5.90 & 24.11 & 21.04 \\
\hline $\mathbf{T}_{3}$ & 24.50 & 4.80 & 23.82 & 5.18 & 6.82 & 28.13 & 24.54 \\
\hline $\mathbf{T}_{4}$ & 24.60 & 4.90 & 27.23 & 5.91 & 7.88 & 32.18 & 28.05 \\
\hline $\mathbf{T}_{5}$ & 24.20 & 4.40 & 17.03 & 3.71 & 4.95 & 20.10 & 17.54 \\
\hline $\mathbf{T}_{6}$ & 24.33 & 4.50 & 20.43 & 4.44 & 5.95 & 24.14 & 21.07 \\
\hline $\mathbf{T}_{7}$ & 24.60 & 4.90 & 23.84 & 5.19 & 6.92 & 28.15 & 24.56 \\
\hline $\mathbf{T}_{8}$ & 24.70 & 5.20 & 27.25 & 5.93 & 7.91 & 32.20 & 28.07 \\
\hline$C D_{0.05}$ & 0.16 & 0.17 & 0.04 & 0.04 & 0.02 & 0.03 & 0.06 \\
\hline
\end{tabular}

\begin{tabular}{|c|c|c|c|c|c|}
\hline \multicolumn{6}{|c|}{ Table.3 Sensory characteristics (scores) of different recipes of wild prickly pear squash } \\
\hline Treatment & Colour & Body & Taste & Aroma & $\begin{array}{c}\text { Overall } \\
\text { acceptability }\end{array}$ \\
\hline $\mathbf{T}_{\mathbf{1}}$ & 7.04 & 6.53 & 6.20 & 6.90 & 6.23 \\
\hline $\mathbf{T}_{\mathbf{2}}$ & 7.20 & 6.81 & 7.16 & 7.10 & 6.60 \\
\hline $\mathbf{T}_{\mathbf{3}}$ & 7.26 & 7.57 & 8.33 & 7.14 & 7.86 \\
\hline $\mathbf{T}_{\mathbf{4}}$ & 7.32 & 7.13 & 7.64 & 7.26 & 7.40 \\
\hline $\mathbf{T}_{\mathbf{5}}$ & 7.05 & 6.41 & 6.53 & 6.93 & 6.33 \\
\hline $\mathbf{T}_{\mathbf{6}}$ & 7.21 & 6.70 & 6.22 & 7.12 & 6.40 \\
\hline $\mathbf{T}_{\mathbf{7}}$ & 7.27 & 6.30 & 5.40 & 7.15 & 6.22 \\
\hline $\mathbf{T}_{\mathbf{8}}$ & 7.34 & 6.31 & 5.23 & 7.28 & 6.14 \\
\hline $\mathbf{C D}_{\mathbf{0 . 0 5}}$ & 0.10 & 0.15 & 0.28 & 0.10 & 0.53 \\
\hline
\end{tabular}


Figure.1 Effect of storage on physico-chemical characteristics of wild prickly pear squash

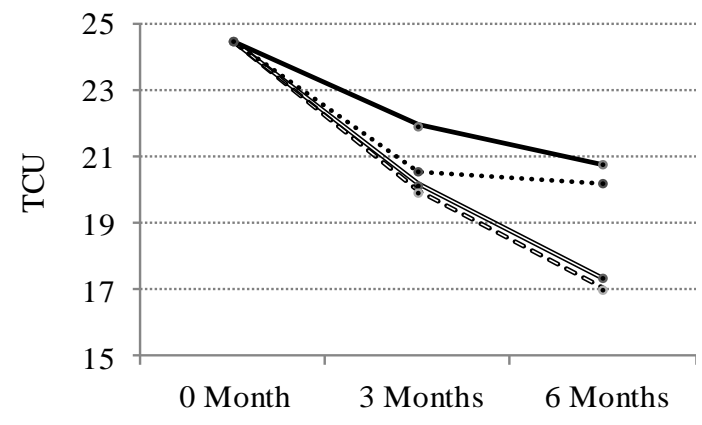

a. Red TCU
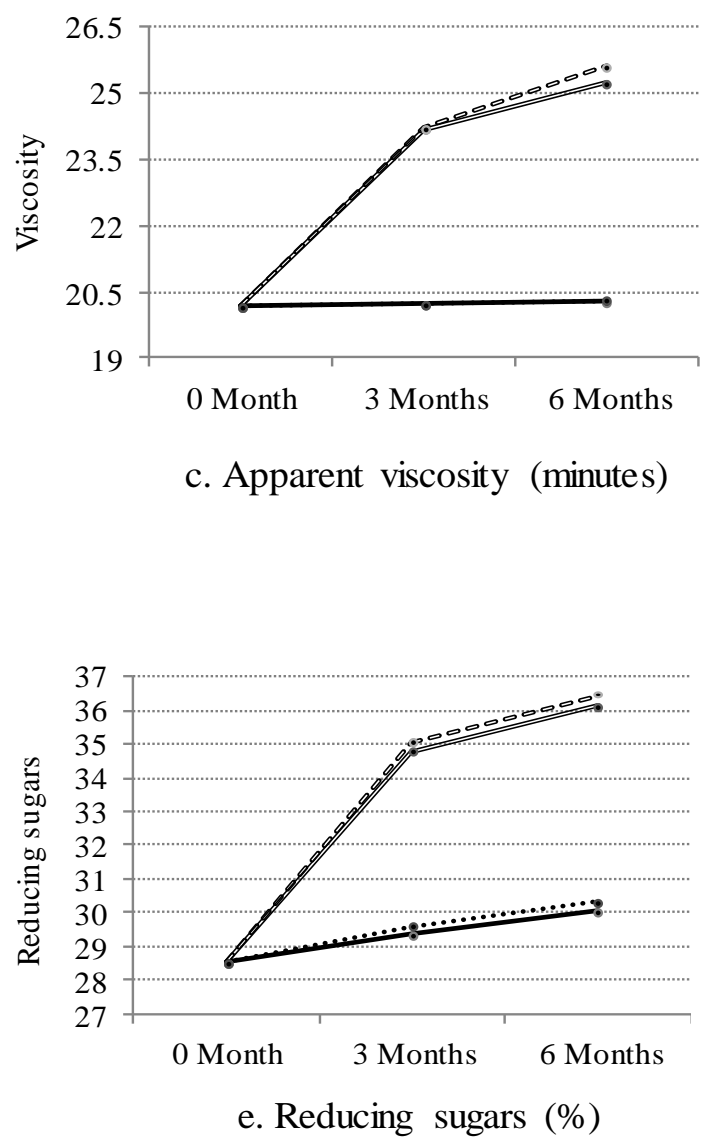

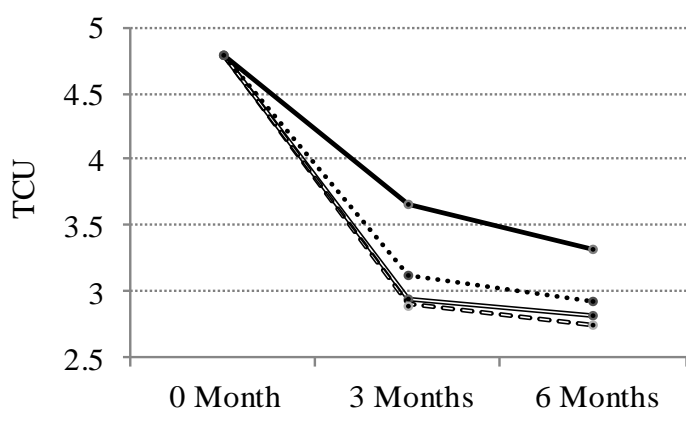

b. Yellow TCU
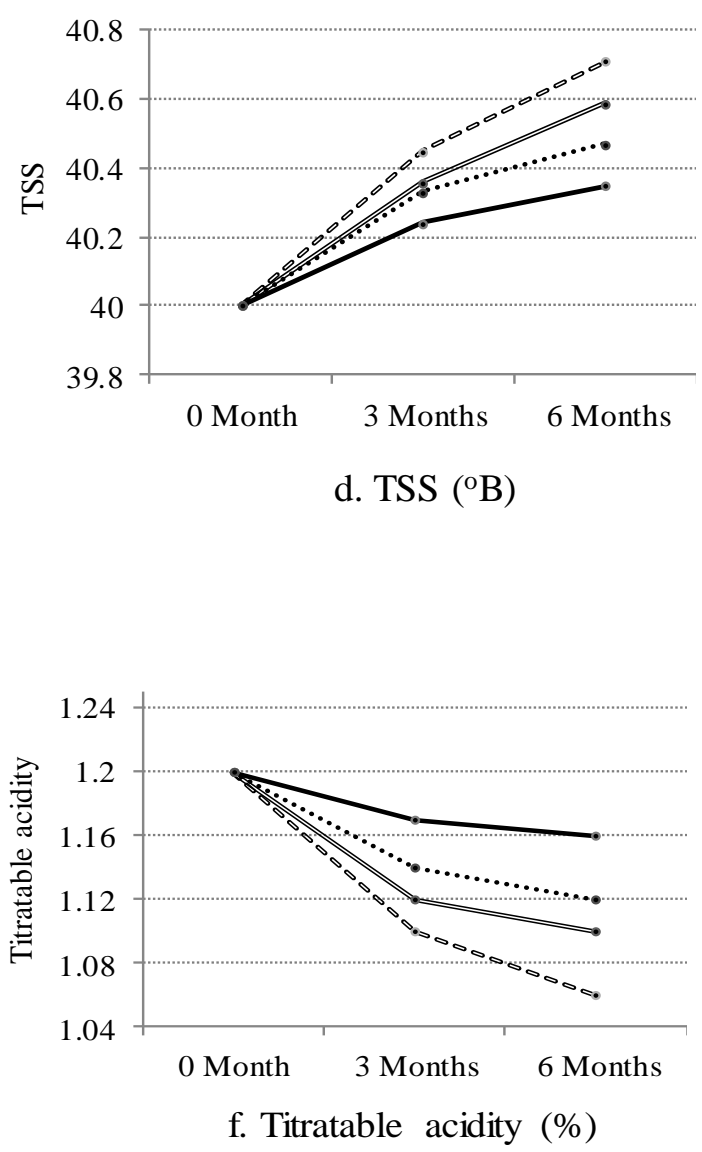

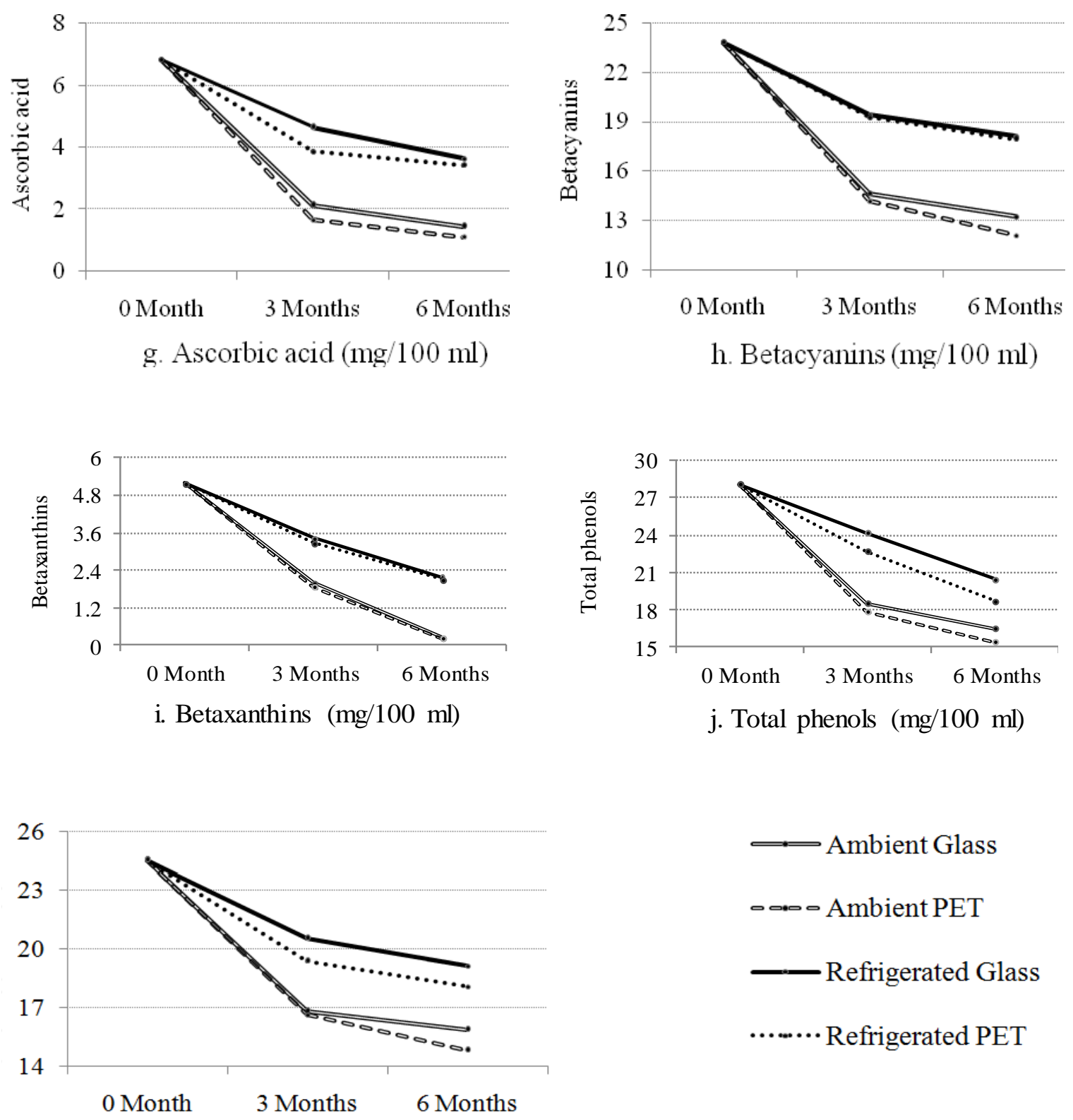

k. Anti-oxidant activity (\%)
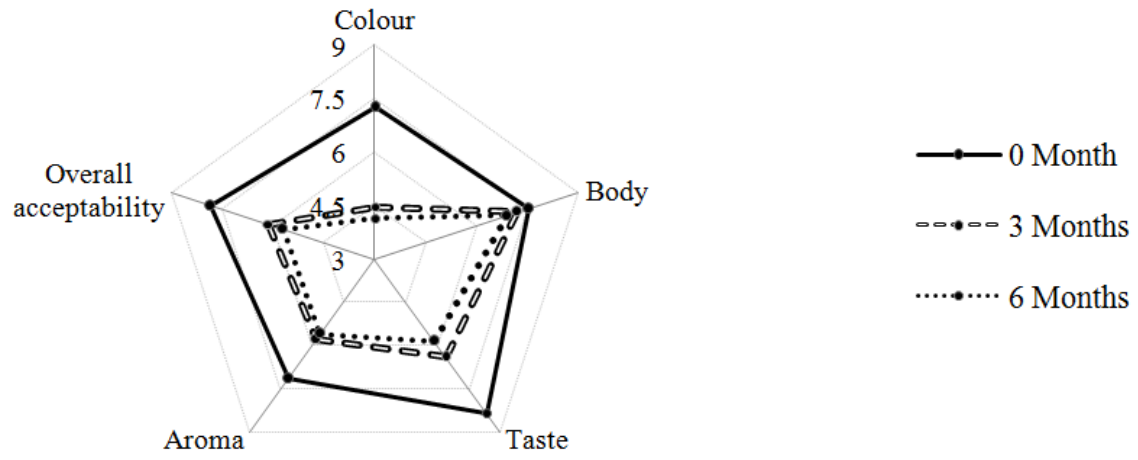

Fig.2 Effect of storage on sensory characteristics of wild prickly pear squash packed in PET bottles stored under ambient conditions 

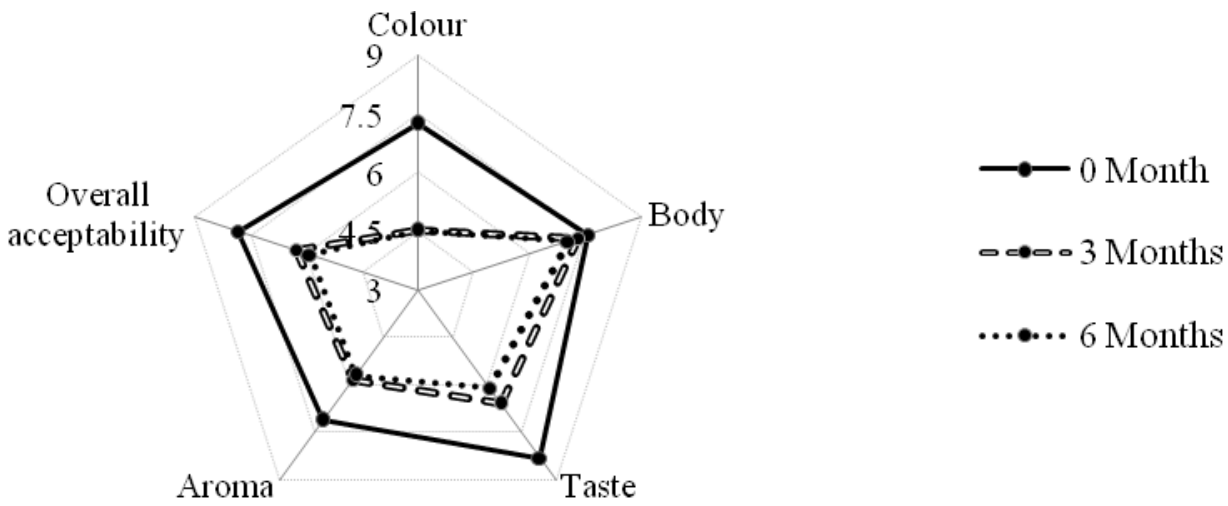

Fig.3 Effect of storage on sensory characteristics of wild prickly pear squash packed in glass bottles stored under ambient conditions.
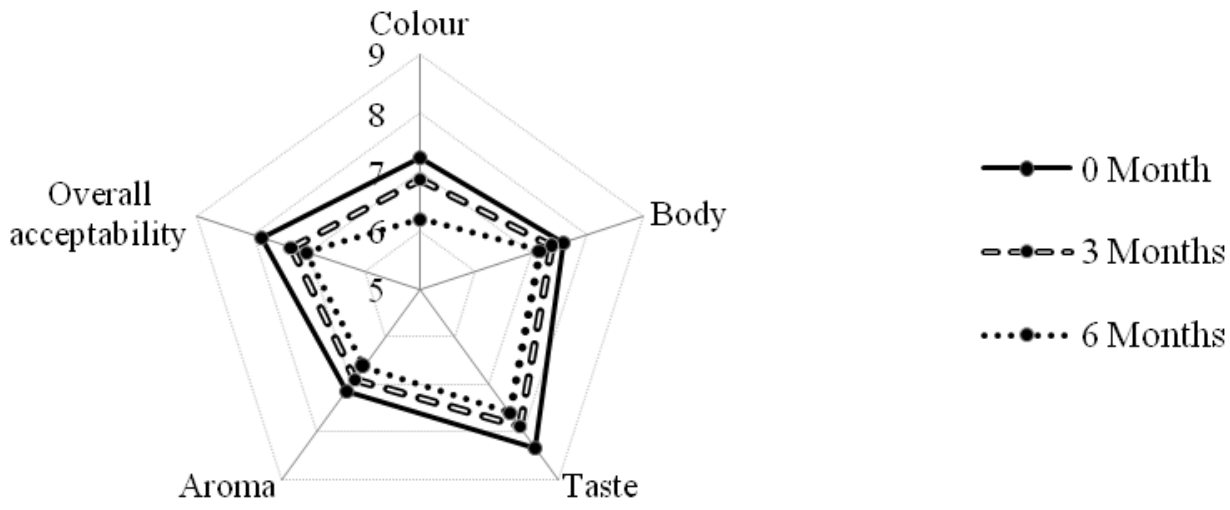

Fig.4 Effect of storage on sensory characteristics of wild prickly pear squash packed in PET bottles stored under refrigerated conditions.
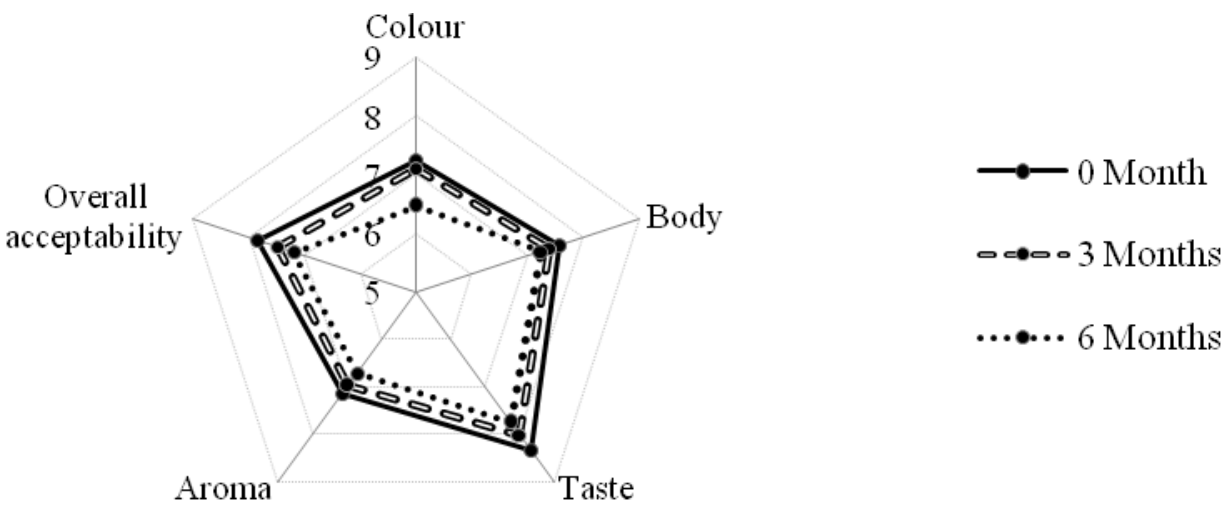

Fig.5 Effect of storage on sensory characteristics of wild prickly pear squash packed in glass bottles stored under refrigerated conditions. 


\section{Reducing sugars}

Reducing sugars of squash (Figure 1e) showed a significant increase in storage which was comparatively less in refrigerated storage conditions than in ambient conditions. This increase might be due to hydrolysis of starch into sugars as well as conversion of complex polysaccharides into simple sugars and hydrolysis or inversion of non-reducing to reducing sugars (Shreshta and Bhatia, 1982). However, as far as the packaging material is concerned, more increase in sugars recorded in squash packed in PET bottle as compared to glass bottle might be due to faster rate of chemical reactions in the product packed in PET bottle as a result of their thermal conductance properties. Our results are in conformity with the findings of Ali et al., (2011) in seabuckthorn squash and Thakur et al., (2016) in box myrtle spiced squash (appetizer).

\section{Titratable acidity}

The squash showed a slight decrease in titratable acidity during storage (Figure 1f) which was comparatively more under ambient conditions as compared to refrigerated conditions. However, with respect to packaging material this decrease was nonsignificant. The decrease in titratable acidity during storage might be due to copolymerization of organic acids with sugars and amino acids (Selvamuthukumaran and Khanum, 2013). Our results are in conformity with the findings of Hussain et al., (2005) in mango squash and Syed et al., (2012) in sweet orange squash.

\section{Ascorbic acid}

Ascorbic acid content of squash decreased significantly during storage however, the decrease was lower in refrigerated storage conditions than ambient (Figure 1g). The decrease in ascorbic acid content might be due to its degradation into dehydro-ascorbic acid or furfural during storage (Ghosh et al., 1982). The findings of the present studies are in agreement with the results reported by Jaiswal et al., (2008) in aonla squash and Hamid and Thakur (2017) in mulberry spiced squash (appetizer).

\section{Betalains}

A significant decrease in betalains (betacyanins and betaxanthins) content of squash was recorded during the storage (Figure $1 \mathrm{~h}$ and 1i) and more retention of betalains was observed under refrigerated storage conditions than ambient conditions. Loss of betalains in squash might be due to their high susceptibility to photo oxidative degradation and poor stability during storage. The possible changes that betalains may undergo during degeneration such as breakdown of the aldimine bond, dehydrogenation, deglycosylation and isomerisation which leads to decrease in the betalains content during storage (Khan, 2016). Similar observations have been reported by Kathiravan et al., (2014) in beet root juice and Kathiravan et al., (2015) in beet root-passion blended juice.

\section{Total phenols}

A significant decrease in total phenol content of squash was recorded during storage (Figure $1 \mathrm{j}$ ) and their decrease was lower under refrigerated storage conditions than ambient. The decrease in the total phenol content of squash during storage might be due to their involvement in the formation of polymeric compounds by complexing with protein and their subsequent precipitations as observed by Abers and Wrolstad (1979). As far as packaging material is concerned, more retention of total phenols in squash packed in glass bottle than PET bottle might be due to 
the difference in their thermal conductance properties which affected internal decomposition reactions. Similar trend of decrease in total phenol content have been reported by Yadav et al., (2014) in guavamango squash and Thakur and Hamid (2017) in mulberry squash.

\section{Antioxidant activity}

A gradual decrease in antioxidant activity of squash (Figure 1k) was observed during storage, which was slower under refrigerated storage conditions than ambient conditions. Significant decrease in antioxidant activity during storage might be due to the degradation of betalains and ascorbic acid during storage period as suggested by MgayaKilima et al., (2015). Slower rate of loss of antioxidant activity in refrigerated storage might be due to slower reaction rate in refrigerated conditions as compared to ambient. However, more antioxidant activity of squash in glass bottle may also be because of slower reaction rates in glass bottle, as glass material absorb heat at slower rate as compared to PET. Nearly, similar observations were recorded by Kathiravan et al., (2014) in beet root squash, and Kathiravan et al., (2015) in beetroot-passion blended juice.

\section{Sensory characteristics of wild prickly pear squash during storage}

The colour, body, taste, aroma and overall acceptability scores of squash decreased significantly during storage (Figure 2-5) and this decrease was more pronounced under ambient storage conditions than refrigerated storage conditions. Retention of higher sensory scores in refrigerated conditions might be due to the slower rate of chemical reactions during storage.

Decrease in colour scores during storage might be due to degradation of colour pigment (betalains) and browning caused by co-polymerization of organic acids of the product and this might have led the judges to award the lower scores during storage. The possible reason for decrease in body scores might be due to the formation of precipitates in the product as a result of interactions between phenols and protein as well as the formation of cation complexes with phenols during storage (Wilson and Burns, 1983). The possible reason for decrease in taste scores might be due to the loss of sugar-acid blend responsible for taste during storage. The decrease in aroma scores during storage might be due to degradation of aromatic compounds in the product (Thakur and Barwal, 1998). There was a decrease in overall acceptability scores of squash during storage, which might be due to the loss in appearance, flavour compounds and uniformity of the product. The retention of better overall sensory scores of squash in glass bottles might be due to the better retention of above given factors as a result of slower reaction rate in glass bottles as compared to PET. The results were in conformity with the finding of Syed et al., (2012) in sweet orange squash, Relekar et al., (2013) in sapota squash and Sharma and Thakur (2017) in bitter gourd aonla blended squash.

In conclusion, the recipe with 35 per cent juice and $40{ }^{\circ} \mathrm{B}$ TSS $\left(\mathrm{T}_{3}\right)$ was found best on the basis of physicochemical and sensory characteristics of the squash. This product could be stored safely for a period of six months under both storage conditions and also in both packaging materials with minimum changes in chemical and sensory attributes. There was an increase in some physico-chemical parameters like viscosity, TSS and reducing sugars while titratable acidity, ascorbic acid, total phenols, betalains (betacyanins and betaxanthins) and antioxidant activity decreased during storage. Various sensory characteristics scores of colour (7.26 to 5.33), body (7.57 to 7.09), 
taste (8.33 to 6.82$)$, aroma (7.14 to 6.17 ) and overall acceptability (7.85 to 6.46) decreased during storage. However, comparatively fewer changes in squash packed in glass bottle and stored under refrigerated storage conditions were observed as compared to PET bottle.

\section{References}

Abers, J.E., and Wrolstad, R.E. 1979. Causative factors of colour determination in strawberry preserves during processing and storage. Journal of Food Science and Technology 44: 7-5.

Ali, Z., Korekar, G., Mundra, S., Yadav, A., and Stobdan, T. 2011. Quality attributes of seabuckthorn squash during storage. Indian Journal of Horticulture 68(4): 479-483.

Bal, L.M., Ahmad, T., Senapati, A.K., and Pandit, P.S. 2014. Evaluation of quality attributes during storage of guava nectar $c v$. Lalit from different pulp and TSS ratio. Food Processing and Technology 5: 349-353.

Brand-Williams, W., Cuvelier, M.E., and Berset, C. 1995. Use of free radical method to evaluate antioxidant activity. Lebensmittel-Wissenschaft and Technologie 28: 25-30.

Castellanos-Santiago, E., and Yahia, EM. 2008. Identification and quantification of betalains from the fruits of 10 Mexican cactus pear cultivars by highperformance liquid chromatography and electrospray ionization mass spectrometry. Journal of Agricultural and Food Chemistry 56: 5758-5764.

Chauhan, M., Thakur, N.S., Thakur, A., and Hamid. 2017. Standardization of enzymatic treatments for the extraction of juice from wild prickly pear (Opuntia dillenii Haw.). Indian Journal of Ecology 44(6): 715-720.
Fernandez, M.L., Lin, E.C.K., Trejo, A., and McNamara, D.J. 1992. Prickly pear (Opuntia sp.) pectin reverse low density lipoprotein receptor suppression induced by a hypercholesterolemic diet in guinea pigs. Journal of Nutrition 22: 22302340.

Ghosh, K.C., Nirmala, M., Krishnappa, K.G., Parmeshwarish, P.M., Broker, H., and Vijayaraghyan, $\quad$ P.K. 1982. Preservation of fruit juice and pulp in flexible pouches. Indian Food Packer 36: 23-26.

Gould, W.A. 1983. Tomato production, processing and quality evaluation. $2^{\text {nd }}$ ed. Avi Publication Cooporation Inc., West port, CJ.

Hamid, and Thakur, N.S. 2017. Development of appetizer (spiced squash) from mulberry (Morus alba L.) and its quality evaluation during storage. Journal of Applied and Natural Science 9(4): 2235-2241.

Hussain, I., Gilani, S.N., Khan, M.R., Khan, M.T., and Shakir, I. 2005. Varietal suitability and storage stability of mango squash. International Journal of Agriculture and Biology 7: 10381039.

Jaiswal, R., Singh, G., and Singh, A.K. 2008. Evaluation of aonla (Emblica officinalis G.) cultivars for squash making. Progressive Agriculture 8: 29-31.

Kannan, S., and Thirumaran, A.S. 2002. Studies on storage behaviour of jamun products. Beverage and Food World 29: 32-33.

Kathiravan, T., Nadanasabapathi, S., and Kumar, R. 2014. Standardization of process condition in batch thermal pasteurization and its effect on antioxidant, pigment and microbial inactivation of Ready to Drink (RTD) beetroot (Beta vulgaris L.) juice. 
International Food Research Journal 21: 1305-1312.

Kathiravan, T., Nadanasabapathi, S., and Kumar, R. 2015. Pigments and antioxidant activity of optimized Ready-to-Drink (RTD) beetroot (Beta vulgaris L.) passion fruit (Passiflora edulis var. flavicarpa) juice blend. Croatian Journal of Food Science and Technology 7: 9-21.

Khan, M.I. 2016. Stabilization of betalains: a review. Food Chemistry 197: 12801258.

Kim, J.H., Park, S.M., Ha, H.J., Moon, C.J., Shin, T.K., Kim, J.M., Lee, N.H., Kim, H.C., Jang, K.J., and Wie, M.B. 2006. Opuntia ficus-indica attenuates neuronal injury in in-vitro and in vivo models of cerebral ischemia. Journal of Ethnopharmacology 104: 257-262.

Lee, E., Kim, H., Song, Y., Jin, C., Lee, K., Cho, J., and Lee, Y. 2003. Constituents of the stems and fruits of Opuntia ficus-indica var. saboten. Archives of Pharmacal Research 26: 1018-1023.

Mahony, M.O. 1985. Sensory evaluation of food: statistical methods and procedures. Marcel Dekker: New York. pp. 168-169.

Mgaya- Kilima, B., Remberg, S.F., Chove, B.E., and Wicklund, T. 2015. Physiochemical and antioxidant properties of roselle- mango juice blends: effects of packaging material, storage temperature and time. Food Science and Nutrition 3: 100-109.

Parmar, C., and Kaushal, M.K. 1982. Opuntia dillenii. In: Wild Fruits. Kalyani publishers, New Delhi. pp. 54-57.

Ranganna, S. 1997. Handbook of analysis and quality control for fruit and vegetable products. Tata McGraw Hill, New Delhi. 1112p.

Relekar, P.P., Naik, A.G., and Padhiar, B.V. 2013. Effect of recipe on qualitative changes in sapota squash during storage. Indian Journal of Horticulture 3: 22-27.

Saenz, C., Berger, H., Galletti, L., Mondragon, C., Arias, E., Garcia, R.C.,Varnero, M.T., Garcia, J.C., Rodriguez-Felix, A., Higuera, I., Rosell, C., and Sepulveda E. 2013. Agro-industrial Utilization of Cactus Pear. FAO, United Nations, Rome. $150 \mathrm{p}$.

Selvamuthukumaran, M., and Khanum, F. 2013. Development of spiced seabuckthorn [Elaeagnus hamnoides (L.)A. Nelson syn. Hippophae rhamnoides L.] mixed fruit squash. Indian Journal of Traditional Knowledge 13: 132-141.

Sharma, R., and Thakur A. 2017. Effect of blending on sensory quality, functional properties and storage stability of bitter gourd - aonla blended squash. Journal of Hill Agriculture 8(2): 234-239.

Sharma, R., Thakur, A., Joshi, V.K., and Sharma, V. 2016. Development and quality evaluation of bitter gourd- kiwi blended squash during storage. International Journal of Food and Fermentation Technology 6: 327-336.

Shreshta, M.K., and Bhatia, B.S., 1982. Apple juice: physico- chemical characteristics and storage studies. Indian Food Packer 36: 53-60

Singelton, V.L., and Rossi, J.A. 1965. Colorimetry of total phenolics with phosphomolybedic phosphotungstic acid reagent. American Journal of Enology and Viticulture 16: 144-158.

Syed, H.M., Ghatge, P.U., Machewad, G., and Pawar, S. 2012. Studies on preparation of squash from sweet orange. Open Access Scientific Reports 1:185-187.

Tesoriere, L., Butera, D., Allegra, M., Fazzari, M., and Liverea, M.A. 2005. Distribution of betalain pigments in 
red blood cells after consumption of cactus pear fruits and increased resistance to the cells of ex-vivo induced oxidative hemolysis in humans. Journal of Agriculture and Food Chemistry 53: 1266-1270.

Thakur, K.S., and Barwal, V.S. 1998. Studies on preparation and evaluation of squash from unmarketable Kiwi fruit. Indian Food Packer 52: 26-29.

Thakur, M., Santran, V.K., and Nigam, A. 2012. Floristic composition and biological spectrum of Darlaghat wild life sanctuary Solan Himachal Pradesh, India. New York Science Journal 5: 1-14.

Thakur, N.S., and Hamid. 2017. Development of squash from mulberry (Morus alba L.) and its quality evaluation during storage. International Journal of Farm Sciences 7: 136-141.

Thakur, N.S., and Thakur, A. 2017. Development of squash from box myrtle (Myrica nagi) and its quality evaluation during storage. Journal of Hill Agriculture 8(1): 87-92.
Thakur, N.S., Dhaygude, G.S., Thakur, A., Kumar P., and Hamid. 2018. Studies on preparation and preservation of squash from wild pomegranate (Punica granatum L.) fruits and its quality evaluation during storage. International Journal of Bio-resource and Stress Management 9(2): 7-12.

Thakur, N.S., Thakur, A. and Joshi, V.K. 2016. Development of appetizer from box myrtle (Myrica nagi) and its quality evaluation during storage. International Journal of Food Fermentation Technology 6(2): 151161.

Wilson, E.L., and Burns, D.J.W. 1983. Kiwi juice processing using heat treatment techniques and ultrafiltration. Journal of Food Science 48: 1101-1105.

Yadav, S., Gehlot, R., Siddiqui, S., and Grewal, R.B. 2014. Changes in chemical constituents and overall acceptability of guava-mango Readyto-Serve (RTS) drink and squash. Beverage and Food World 41: 30-33.

\section{How to cite this article:}

Thakur, N.S., Monika Chauhan and Abhimanyu Thakur. 2018. Development of Squash from Wild Prickly Pear (Opuntia dillenii Haw.) Fruit and Its Quality Evaluation During Storage. Int.J.Curr.Microbiol.App.Sci. 7(07): 1942-1954. doi: https://doi.org/10.20546/ijcmas.2018.707.229 